\title{
Pengembangan Lembar Kerja Peserta Didik (LKPD) Berbasis Inkuiri pada Materi Sistem Sirkulasi di SMA Negeri 5 Palangka Raya
}

\author{
I Made Darma Yase ${ }^{{ }^{\star}}$, Bejo Basuki ${ }^{1}$, Shanty Savitri ${ }^{1}$ \\ ${ }^{1}$ Program Studi Pendidikan Biologi, Fakultas Keguruan dan Ilmu Pendidikan, Universitas Palangka Raya, \\ Kota Palangka Raya, Indonesia \\ *email: boyyasa45@gmail.com
}

Kata Kuci:

ADDIE

Inkuiri

LKPD

Sistem Sirkulasi

Uji Golongan Darah

Submitted: 29/08/2020

Revised: 09/10/2020

Accepted: 01/12/2020

\begin{abstract}
Abstrak. LKPD merupakan salah satu sumber belajar yang dapat dikembangkan oleh pendidik sebagai fasilitator dalam kegiatan pembelajaran. LKPD merupakan lembaran-lembaran berisi tugas yang dikerjakan oleh peserta didik, berisi petunjuk, langkah-langkah untuk menyelesaikan suatu tugas berupa teori ataupun praktik. Keterbatasan LKPD yang digunakan di sekolah menyebabkan peserta didik kesulitan memahami praktikum dan menjadi lebih pasif, dimana LKPD di sekolah hanya berisikan topik, tujuan, cara kerja secara singkat, dan beberapa soal evaluasi. Tujuan penelitian ini adalah untuk mengetahui kualitas LKPD berbasis Inkuiri yang dikembangkan dan untuk mengetahui respon peserta didik. Pengembangan LKPD berbasis inkuiri menggunakan metode penelitian dan pengembangan atau research \& development (R\&D) dengan model ADDIE (Analysis, Design, Development, Implementation and Evaluations). LKPD hasil pengembangan divalidasi oleh ahli materi, ahli media \& pembelajaran, ahli bahasa dan guru, serta diuji pada peserta didik untuk melihat responsnya. Instrumen yang digunakan dalam penelitian ini berupa angket. Angket digunakan pada validasi ahli, respons guru, dan respons peserta didik untuk mengumpulkan data. Data yang didapat dianalisis menggunakan rumus kriteria kualitas. Hasil penelitian menunjukkan bahwa LKPD berbasis inkuiri hasil pengembangan layak untuk digunakan berdasarkan validasi oleh ahli materi sebesar $65 \%$ termasuk kriteria baik, ahli media \& pembelajaran sebesar $96 \%$ termasuk kriteria sangat baik, ahli bahasa sebesar $95 \%$ dengan kriteria sangat baik dan respons guru sebesar $77 \%$ dengan kriteria sangat baik, dan respons peserta didik terhadap LKPD yang dikembangkan sebesar $85 \%$ dengan kriteria sangat menarik \& sangat membantu.
\end{abstract}




\section{PENDAHULUAN}

Proses pembelajaran memerlukan adanya bahan ajar yang dapat membantu peserta didik untuk belajar aktif. Salah satu bahan ajar berupa lembar kerja peserta didik (LKPD). LKPD merupakan salah satu sumber belajar yang dapat dikembangkan oleh pendidik sebagai fasilitator dalam kegiatan pembelajaran. Menurut Depdiknas (2014), LKPD merupakan lembaranlembaran berisi tugas yang dikerjakan oleh peserta didik, berisi petunjuk, langkahlangkah untuk menyelesaikan suatu tugas berupa teori ataupun praktik. LKPD yang disusun dapat dirancang dan dikembangkan sesuai dengan kondisi dan situasi kegiatan pembelajaran yang akan dihadapi (Widjajanti, 2008).

Lembar kerja peserta didik (LKPD) merupakan salah satu bentuk program yang berlandasan atas tugas yang harus diselesaikan dan berfungsi sebagai alat untuk mengarahkan peserta didik untuk menemukan konsep-konsep melalui aktivitas sendiri dan memberikan pengalaman langsung kepada diri sendiri (Estianti, 2008). Penggunaan LKPD tidak akan optimal, tanpa menggunakan model pembelajaran dalam proses pembelajaran. Pembelajaran dalam kurikulum 2013 mengutamakan pendekatan saintifik. Salah satu model pembelajaran yang menerapkan pendekatan saintifik adalah inkuiri.

Tujuan penelitian ini adalah untuk mengetahui tingkat kualitas LKPD yang dikembangkan melalui penilaian ahli media \& pembelajaran, ahli materi, ahli bahasa dan untuk mengetahui respons guru dan peserta didik terhadap LKPD tang dikembangkan.

\section{METODE}

Penelitian ini menggunakan metode penelitian Research and Development yang dilakukan di SMAN 5 Palangka Raya. Subjek penelitian ini adalah peserta didik kelas XI MIPA 4 dengan jumlah 35 orang.

Model yang digunakan pada penelitian ini adalah model ADDIE (Analysis, Desaign, Development, Implementation, evaluation). Teknik pengumpulan data dilakukan dengan cara wawancara dan angket. Wawancara digunakan saat melakukan observasi dan angket digunakan untuk validasi LKPD pengembangan serta untuk mengetahui respons guru \& peserta didik. Analisis data validasi ahli diperoleh dari penilaian ahli media \& pembelajaran, ahli materi, ahli Bahasa, serta analisis data untuk repons diperoleh dari guru bidang studi dan peserta didik berdasarkan angket yang diberikan.

Data validasi ahli kemudian dianalisis dengan rumus:

Persentase (\%) $=\frac{\text { Total Skor Jawaban }}{N \times \text { Bobot Terting gi }} \times 100 \%$

Kriteria penskoran validitas disajikan pada tabel berikut:

Tabel 1. Kriteria Penskoran Validitas

\begin{tabular}{ll}
\hline Respons (\%) & Kriteria \\
\hline $81-100$ & Sangat Baik \\
$61-80$ & Baik \\
$41-60$ & Cukup Baik \\
$21-40$ & Kurang Baik \\
$1-20$ & Sangat Kurang Baik \\
\hline
\end{tabular}

Data respons guru dan peserta didik dianalisis dengan menggunakan rumus skala Llikert (Sari, 2016):

$$
V=\frac{A}{B} \times 100 \%
$$


Keterangan:

V : Persentase Nilai

A : Skor Perolehan

B : Skor Maksimum

Kriteria respon guru dan siswa disajikan pada table-tabel berikut:

Tabel 2. Kriteria Penilaian Respon Guru

\begin{tabular}{cc}
\hline Kriteria & $\%$ Nilai \\
\hline Sangat Baik & $76-100$ \\
Baik & $51-75$ \\
Cukup Baik & $26-50$ \\
Kurang Baik & $\leq 25$ \\
\hline
\end{tabular}

Tabel 3. Kriteria Penilaian Respon Siswa

\begin{tabular}{cc}
\hline Kriteria & $\%$ Nilai \\
\hline $\begin{array}{c}\text { Sangat Menarik \& Sangat } \\
\text { Membantu }\end{array}$ & $76-100$ \\
Sangat Menarik & $51-75$ \\
Cukup Menarik \& Cukup & $26-50$ \\
Membantu & $\leq 25$ \\
Kurang Menarik \& Kurang & \\
Membantu &
\end{tabular}

\section{HASIL DAN PEMBAHASAN}

Hasil dari penelitian pengembangan ini adalah produk LKPD berbasis Inkuiri yang telah divalidasi oleh ahli, dan telah dinilai oleh guru dan peserta didik untuk mengetahui respons mereka terhadap LKPD tersebut.

\subsection{Validasi Ahli}

Validasi ahli media \& pembelajaran adalah Ibu Dr. Yula Miranda, M.Pd. Hasil analisis data validasi ahli media diperoleh nilai $96,66 \%$, dan berdasarkan tabel kriteria masuk dalam kriteria sangat baik, sehingga layak untuk digunakan dalam proses pembelajaran. Adapun saran dan perbaikan yang diberikan oleh ahli media \& pembelajaran yaitu perbaikan pada kata pengantar, lembar redaksi, penulisan daftar pustaka, isi materi, serta margin LKPD.

Validasi ahli materi adalah Bapak Bintang Sariyatno, S.SI., M.Pd. Hasil analisis data validasi ahli materi diperoleh nilai $65 \%$ dan berdasarkan tabel kriteria masuk dalam kriteria baik, sehingga layak untuk digunakan dalam proses pembelajaran. Adapun saran dan perbaikan yang diberikan oleh ahli materi yaitu dimasukan sumber untuk dasart teori dan sumber gambar pada dasar teori.

Validasi ahli bahasa adalah Ibu Alifiah Nurachmana, S.S., M.Pd. Hasil analisis data validasi ahli bahasa diperoleh nilai 95\%, dan berdasarkan tabel kriteria masuk dalam kriteria sangat baik, sehingga layak digunakan dalam proses pembelajaran. Adapun saran dan perbaikan yang diberikan oleh ahli bahasa yaitu perbaikan pada beberapa ejaan kata, dan sampul LKPD ditambahkan warna merah.

\subsection{Respon Guru dan Siswa}

Guru Biologi yang memberikan respons terhadapa LKPD yang dikembangkan adalah Ibu Anastasia Sumaryani, M.Pd. Hasil analisis data untuk repons guru diperoleh nilai $77,5 \%$, dan berdasarkan tabel kriteria masuk dalam kriteria sangat baik, sehingga layak digunakan dalam proses pembelajaran. Hasil respons peserta didik diperoleh dari peserta didik kelas XI MIPA 4 yang berjumlah 35 orang. Respons peserta didik terbagi menjadi 2 bagian yaitu respons uji skala kecil (jumlah peserta didik setengah atau kurang, dari total peserta didik di dalam 1 kelas) dan uji skala besar (seluruh peserta didik di dalam 1 kelas). Saat uji skala kecil dengan jumlah peserta didik 12 orang, diperoleh nilai sebesar $74,03 \%$ dan berdasarkan tabel kriteria masuk dalam kriteria menarik \& membantu. Saat uji skala besar dengan jumlah peserta 
didik 35 orang, diperoleh nilai sebesar 85,03\% dan berdasarkan tabel kriteria masuk dalam kriteria sangat menarik \& sangat membantu, sehingga layak digunakan dalam proses pembelajaran.

\section{KESIMPULAN}

Produk LKPD berbasis inkuiri pada pembelajaran Biologi materi Sistem Sirkulasi sub materi golongan darah telah memenuhi kriteria valid dari penilaian validator ahli media dan pembelajaran sebasar $96,66 \%$, ahli materi sebesar $65 \%$, ahli bahasa sebesar 95\% dan respon guru mata pelajaran Biologi sebesar $77,5 \%$. Respon peserta didik pada produk LKPD berbasis Inkuiri pada materi sistem sirkulasi sub materi golongan darah yang telah dikembangkan mendapatkan respon yang sangat baik, dimana hasilnya menunjukan respon ketertarikan peserta didik dalam menggunakan LKPD sebesar 85,03\% yang tergolong dalam kriteria sangat menarik \& sangat membantu.

\section{Ucapan Terima Kasih}

Penulis mengucapkan terima kasih kepada Ida Sang Hyang Widhi Wasa (Tuhan Yang Maha Esa), Orang tua dan keluarga yang telah membrikan dukungan penuh terhadap studi saya. Penulis juga mengucapkan terima kasih kepada Pembimbing 1 Bapak Drs. Bejo Basuki, M.Si., Pembimbing 2 lbu Shanty Savitri, S.Si.,M.Pd. yang telah membimbing, mengarahkan, dan mengajarkan segala hal sehingga penelitian ini dapat selesai. Penulis juga mengucapkan terima kasih kepada para kerabat kuliah (MK) yang juga memberikan dukungan kepada saya.

\section{Referensi}

Astuti, Y. dan Setiawan. 2013. Pengembangan Lembar Kerja Siswa (LKS) Berbasis Pendekatan Inkuiri Terbimbing Dalam Pembelajaran Kooperatif Pada Materi Kalor. Jurnal Pendidikan IPA Indonesia (JPII 2)1(2), 88-92.

Borg. W.R. \& Gall, M.D. (1983) Educational Research: An Introduction. New York: Longman.

Depdiknas. 2008. Panduan Pengembangan Bahan Ajar. Jakarta: Departemen Pendidikan Nasional Direktorat Jenderal Manajemen Pendidikan Dasar dan Menengah Direktorat Pembinaan Sekolah Menengah Atas.

Emanuela, M. 2015. Penerapan Pendekatan Scientific untuk Meningkatkan Prestasi Belajar Siswa pada Mata Pelajaran Ekonomi Pokok Bahasan Pasar. Universitas negeri surabaya. Surabaya. $17 \mathrm{hlm}$.

Gall, Meredith D., Gall, Joyce p., Borg, Walter R. 2003. Educational Research. Newyork: Allyn and Bacon.

Jauhar, M. 2011. Implementasi PAIKEM dari Behavioristik sampai Konstruktivistik. Jakarta: Prestasi Pustakaraya.

Katriani, Laila.2014. Pengembangan Lembar Kerja Peserta Didik (LKPD). Yogyakarta: Universitas Negeri Yogyakarta.

Majid, A. (2013). Strategi Pembelajaran. Bandung: Remaja Rosdakarya.

Mulyasana, Dedy. 2011. Pendidikan Bermutu dan Berdaya Saing. Remaja Rosdakarya. Bandung.

Prastowo, Andi. 2011. Bahan Ajar Inovatif. Yogjakarta: DIVA Press. 
Sanjaya, W. (2006). Strategi Pembelajaran Berorientasi Standar Proses

Pendidikan. Jakarta: Kencana Prenada Media Group.

Trianto. 2010. Mendesain Model Pembelajaran Inovatif-Progresif. Jakarta: Prenada Media Group.

Wena, M. (2011). Strategi Pembelajaran Inovatif Kontemporer Suatu Tinjauan Konseptual Oprasional. Jakarta: Bumi Aksara.

Widjajanti, E. (2008). Pelatihan Penyusunan LKS Mata Pelajaran Kimia Berdasarkan KTSP bagi Guru SMK/MAK . Yogyakarta: Ruang Sidang Kimia FMIPA UNY.

Widyantini, Theresia. 2013. Penyusunan Lembar Kegiatan Siswa (LKS) Sebagai Bahan Ajar. Yogyakarta : PPPPTK Matematika.

Wijaya. 2006. Upaya Pembaharuan dalam pendidikan dan pengajaran. Bandung: PT.Rosda Karya. 